\title{
South Africa's lockdown regulations and the reinforcement of anti-informality bias
}

\author{
Jane Battersby ${ }^{1}$ \\ Accepted: 24 April 2020 / Published online: 11 May 2020 \\ (c) Springer Nature B.V. 2020
}

This was written in the 4th week of South Africa's lockdown period, when the country had 3465 reported Covid- 19 cases and 58 deaths. It was also the week in which looting of formal and informal retailers, food trucks and distributors of food parcels began.

South Africa has been widely lauded for its swift and decisive Covid-19 action. A National State of Disaster was announced when we had just 61 cases, and lockdown announced when we had 1170 cases and one death-the result of concerns about the impacts of the virus in a country with dense informal settlements, poor access to water, a weak public health sector and high levels of TB, HIV, hypertension and malnutrition.

However, the State's attempts to "flatten the curve" include a set of regulations that demonstrate limited understanding of how the poor access food and an ongoing bias towards large scale, formal food system actors.

Our research has found consistently higher levels of food insecurity than official statistics present. Our work also indicates how poor households depend on a range of formal and informal food retail sources to meet their food needs. The informal sector provides food in affordable unit sizes, provides food on credit, sells fresh produce at lower costs than supermarket fresh produce and sells prepared foods appropriate for households that experience income, time, storage and energy poverty (Battersby et al. 2016).

And yet, when the lockdown measures were first announced the President said that the only food retailers that could open were supermarkets. The official lockdown regulations were expanded to include spaza shops ${ }^{1}$ (Minister of COGTA 2020). However, confusion about what permitting

This article is part of the Topical Collection: Agriculture, Food \& Covid-19.

Jane Battersby

jane.battersby.lennard@gmail.com

1 African Centre for Cities, University of Cape Town, Cape Town, South Africa was required for spazas to operate and the Minister of Small Business Development's later retracted statement that only South African stores would be able to operate meant that law enforcement forced many legitimately open spazas to close. Foreign owned spazas (about $80 \%$ of all spazas) have been most targeted (Githahu 2020).

Only after two weeks of lockdown were informal food vendors allowed to start selling again, and only those selling uncooked foods with existing municipal permits. Most township vendors had previously operated without permits, and were therefore now unable to legally operate under lockdown. While the State had previously often turned a blind eye, law enforcement officers have now been forcefully closing down these businesses.

In the fourth week of lockdown, the State finally announced support for spazas. However, amongst the exclusionary conditions to obtain this relief are registration with the South African Revenue Service and South African citizenship (DSBD 2020).

The government's lockdown regulations have demonstrated considerable bias towards the large-scale formal actors and pushed towards formalization of the informal sector through the conditions about who is able to operate and the conditions placed on relief measures. These reflect historical biases against informality, the Africa-wide modernization agenda and the power of large scale food businesses to self-identify as partners-in-development (Battersby 2017).

While there have been many hopeful statements that the food system will transform positively post-Covid-19, the South African case suggests that in a state of crisis, governments with wilfully poor understandings of the food systems of the masses will develop regulatory responses that will rather lead to further consolidation of the food system rather than usher in potentially transformed food systems.

\footnotetext{
${ }_{1}$ Small informal general dealers predominantly in lower income areas.
} 


\section{References}

Battersby, J. 2017. Cities, planning and urban food poverty in Africa. Companion to planning in the global south, 204-214. London: Routledge.

Battersby, J., Marshak, M. and Mngqibisa, N. 2016. No. 24: Mapping the Invisible: The Informal Food Economy of Cape Town, South Africa, AFSUN Urban Food Security Series, Cape Town. https:// scholars.wlu.ca/cgi/viewcontent.cgi? article $=1023 \&$ context $=$ afsun . Accessed 22 Apr 2020.

DSBD (Department of Small Business Development. 2020. Guidelines for participation in the spazashops and general dealers support scheme in partnership with Nedbank.. https://www.dsbd.gov.za/ wp-content/uploads/2020/04/GUIDELINES-FOR-PARTICIPAT ION-IN-THE-SPAZASHOPS-AND-GENERAL-DEALERSSUPPORT-SCHEME.pdf. Accessed 22 Apr 2020.

Githahu, M. 2020. Call for clarity on spaza shops during Covid-19 lockdown, Cape Argus. https://www.iol.co.za/capeargus/news/ call-for-clarity-on-spaza-shops-during-covid-19-lockdown-45856 999. Accessed 31 Mar 2020.
Minister of COGTA. 2020. Disaster Management Act (57/2002): Regulations made in terms of Section 27(2) by the Minister of Cooperative Governance and Traditional Affairs, Government Gazette, South African Government no. 43148, 25 March 2020, pp. 3-16. https://www.gov.za/sites/default/files/gcis_document/20200 3/4314825-3cogta.pdf. Accessed 22 Apr 2020.

Publisher's Note Springer Nature remains neutral with regard to jurisdictional claims in published maps and institutional affiliations.

Jane Battersby is an Associate Professor at the African Centre for Cities, University of Cape Town. Her research focusses on urban food security and food systems in African cities. She has particular interests in the role of spatial planning in shaping food environments and local and global food systems governance discourses and practices. 